\title{
„ЈЕЗИЧКО ПИТАЊЕ“ КОД ГРКА И СРБА
}

Култура и криза немају, бар на први поглед ништа заједничко, чак изгледа да једна другу искључују, у смислу, inter arma, tacent musae. Историја показује да неминовно постоји узајамност кризе и културе, али не и да се оне морају међусобно условљавати. Када култура у „тешким временима“ посустане, криза јој може бити подстицај, јер и једна и друга представљају људско дел(ов)ање, које претпоставља свесну активност. Античка Грчка практично је неисцрпни извор примера за истраживање (узајамних) односа културе и кризе, поготово када је реч о језику, а није било другачије ни у потоњим вековима: грчки језик и књижевност, која траје тридесет векова, омогућавају таква истраживања. Најзад, Грци и Срби су, без обзира на посебности, умногоме прешли сличан пут, чему је допринела и геополитичка ситуација новог доба.

Кључне речи: диглосија, катаревуса, димотика, „језичко питање“, Грци, Срби, Жан Психари

\section{Увод}

Значење речи криза померало се од основног значења разлучивање, избор, оgлука, и даље ${ }^{1}$, у класичном грчком све до садашњег значења “одлучни тренутак у следу (друштвене) нестабилности, када долази до (политичког, економског или неког другог) обрта који значи прекретницу“. Криза, уосталом као и критика², нема (само) негативно значење, како се често поједностављено схвата, него су то појмови којима се означавају последице углавном људског дел(ов)ања, које захтевају да се чињенице и околности најпре сагледају, рашчлане,

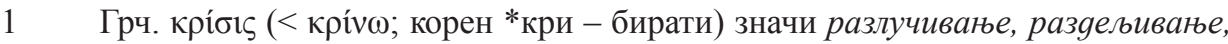
раз(а)бирање, разликовање; бирање, избор; неслайање; одлучивање, оgлука (< лучити), расуђивање, иросуђивање, ирресуђивање, суg, исхоg; йешко сииање (у болести, животним околностима), итд.

2 Реч критиика има исти корен као реч криза. 
просуде и да се напослетку донесу одлуке које, када је реч о кризним ситуацијама, могу имати и позитиван и негативан исход. Ипак, криза се најчешће схвата у негативном значењу, чак и онда када има позитиван исход, највише због околности које су је изазвале и, наравно, због тешкоћа и ризика који се морају савладати. Криза генерално изазива страх, јер најчешће, бар у почетку, нису видљиве „стране у сукобу“, па ни последице, које, појединачно гледано, никога не штеде. Отуда су људи углавном немоћни да кризу предупреде, или не знају шта да ураде, и при том су свесни да ће по свој прилици једни испаштати због неминовних последица, а други, они који су је изазвали, са разних разлога, најчешће бити недодирљиви. Зато се често дешавало да немоћ пред политичком кризом прерасте у насиље, рат, револуцију, итд. Језик, међутим, у политичком смислу никада није било непосредан и најбитнији casus belli, али је бивао фактор ризика „на дуге стазе“, тзв. „сукоба ниског интензитета“", у двема, поготово суседним, а сукобљеним, друштвеним заједницама, које говоре више или мање различитим језицима ${ }^{3}$. Да ли ће победник у сукобу наметнути свој језик у циљу асимилације побеђеног, или се то питање неће чак ни поставити, зависи од околности.

Диглосија ${ }^{4}$ означава друштвену ситуацију унутар једне исте друштвене заједнице, у којој се један језик говори на два начина, од којих сваки има своју намену, сврху или циљ, с тим што немају исти друштвени положај, пре свега у образовном систему, тако да један од њих обично постане инфериоран у културном погледу због супремације оног другог. Уколико је инфериоран језик којим већина „по природи“ говори, а намеће се онај којим „треба“" говорити, онда може доћи до кризе и конфронтације присталица супротстављених језика. То није сукоб „говорника“ једног и „говорника“ другог језика, који обично говоре мање-више исто, него је предмет сукобљавања питање књижевног језика, односно службеног или званичног у најширем смислу, нпр. језик образовања или администрације. Такво питање је неизоставно од интереса за целу заједницу, а може се свести на прописивање којим ће се језиком писати.

Таква конфронтација „два“ језика унутар исте друштвене заједнице одвијала се код Срба и код Грка, свака за себе довољно специ-

3 Људи често мистификују разлике у два сродна језика, тако што га обично „чисте“ од свих могућих туђих и туђинских елемената, или, шире посматрано, уклањају утицаје другости, често с тенденцијом да другост уклоне у потпуности.

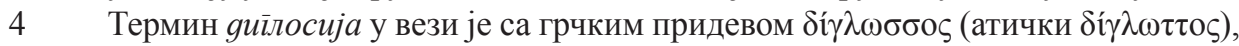
у значењу „онај ко говори два језика“, први пут документован код Тукидида (5. в. п. н.е.), и касније код других аутора, са извесним разликама у значењу. 
фична. Но, без обзира на посебности, и једни и други су умногоме прешли сличан пут, чему је свој обол дала геополитичка ситуација новог доба. Оба народа су била под туђинском влашћу ${ }^{5}$ и ослободивши се (Турака) стварала су сопствене, националне, државе током 19. века. Нису та два балканска народа била изузетак у том погледу, али су их историјске околности и вековне везе учиниле блискијим, готово сродним $^{6}$, без обзира на језичке и друге различитости, нарочито културне.

\section{Грци}

Случај грчког језика је свакако јединствен, чак и у односу на латински, јер јесте остао језик једне заједнице, а истовремено је постао интернационални језик, наравно не у смислу споразумевања. Значај класичног грчког (или обичније старогрчког) језика за европску културу практично је немерљив, с тим што му се од осталих језика само латински може приближити, али треба истаћи да је и сам латински, поготово када је реч о језику и књижевности, па и о култури ${ }^{7}$ генерално, био под утицајем грчког ${ }^{8}$. И не само

5 Већи део народа, и једног и другог, био је под турском влашћу. Мањи део српског народа је био у Хабзбуршкој монархији, од 1867. у Аустро-Угарској, а Грцима, који су насељавали острва, владали су углавном Млечани, Французи, Енглези (острва у Јонском мору Турци нису никад освојили, за разлику од острва у Егејском мору, Крита и Кипра).

6 Како је схватана разлика између класичног грчког, или "еллинскогъ", језика и "подмлађеногъ" или "еллиногрчкогъ" језика, сасвим јасно објашњава Јевтимије Аврамовић, професор "еллиногрчкогь" језика у београдској гимназији у предго-

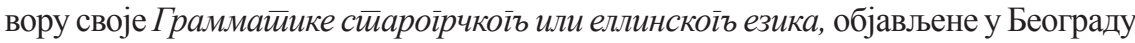
1856. године. Он не само што се позивао на стару изреку "колико језика знаш толико људи вредиш", него је Европу схватао на неки начин као "пространіе отечество", те да је грчки језик за нас "знатанъ" као језик народа који нам је суседан, "и веромъ и животомъ, као и чудномъ своіомъ судбомъ изближе сроданъ".

7 Сама реч кулйура је латинска (cultura < colo colere, colui, cultum) и значи кулйура уопште, затим корисна биљна куличура, нпр. винова лоза, обрађивағе земље; значи и кулимура духа и кулииивисање у смислу образовати некога. Нај-

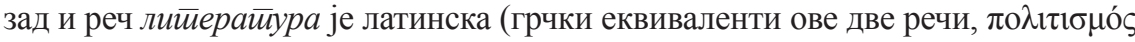

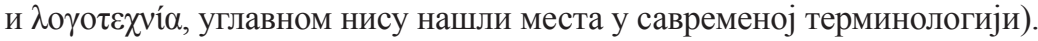

8 Овде није реч о мерењу (узајамних) утицаја грчког и латинског (језика, књижевности, културе) него о (привидној) противуречности у томе што је освајача освојио освојени, како то Хорације каже: „Graecia capta ferum victorem cepit et artes intulit agresti Latio“ (Hor., Epist., II, 156-157) 
то, грчки је језик са најдужом непрекидном историјом у Европи, а његова је књижевност, према ономе што се зна, најстарија европска књижевност с обзиром да траје више од тридесет векова. Може се рећи да је класични грчки, са својом књижевношћу био и остао основа и трајни извор европских култура. То је оно што се може уопштено рећи. Појединачно, сваки (живи) језик има различит однос према класичном грчком, што на неки начин важи и за модерни грчки језик, односно новогрчки, како се то најчешће каже.

Грцима је било одувек јасно да се људи разликују не само по језицима, него и по употреби сопственог, грчког, јер га карактеришу дијалекти ${ }^{9}$ и разне друге разлике у говору, на пример, разлике између образованих и необразованих људи. Говорни грчки, ма колико се ослањао на стари грчки језик ${ }^{10}$, временом се све више мењао и удаљавао од предачког језика. При том се све више разликовао и од књижевног (,писаног“") језика ${ }^{11}$, који није настао од народног ${ }^{12}$, што је било уоби-

„Grčka je svladana bila, no pobjednika svog svlada, pri tom umijeća, ko uzvrat, u seljački unese Lacij. (Horacije (1958), Satire $i$ epistule, preveo Juraj Zgorelec, Zagreb: Matica Hrvatska, 138). Парадигматичан је случај Катона Старијег (234-149), који је, како каже Цицерон у спису $O$ стиаростии, дуго одбијао да научи грчки, али је, већ дубоко у годинама, ипак попустио и на крају научио. И не само што је научио, него је то знање искористио у свом стварању.

9 Неки дијалекти су били и књижевни (у неким књижевним врстама обавезни).

10 Тај стари атички дијалекат, који је послужио као основа модерног грчког језика, говорио се у Атини (и у Атици) представљајући узор или образац (атицизам) и у античко време и касније. Његов процват, или врхунац, хронолошки се обично везује за Периклово (495-429) ,златно доба““ премоћи Атине после Персијских ратова, 480/479, које се обично назива и пентеконтаетијом (педесет година), а завршава се формалном објавом рата Спарте Атини 431. године када почињу Пелопонески ратови.

11 Чињеница да се говорни језик брже мења него књижевни, али и да се књижевни мења, само не истим темпом као говорни, најбоље се уочава управо на примеру класичног грчког, који нам је познат првенствено као књижевни језик. Мешања народа и мешања језика уз смењивање грчког и латинског као језика комуникације или званичног (јавног) језика (нарочито администрације) довели су до већег утицаја не-књижевних варијетета грчког језика, што се зависно од геополитичке ситуације наставило све до данас.

12 Настао је од оног језика предака који су имали, а ти је био језик књижевности, који је у четвртом веку н. е. био неразумљив ономе које је необразован, о чему су сами (високо образовани) Грци оставили сведочанства у својим списима. 
чајено за друге језике па и за српски. Тако је настала диглосија, унутар истог језика, са две сврхе, која је била сама по себи разумљива све до времена (19. века), када народни језик под разним утицајима постаје императив (нео)романтичарске оригиналности у Европи, и самим тим и за Грке и за Србе, што ће изазвати потресе у обема друштвеним заједницама. Не треба сметнути с ума ни то да је за Европу био већи (културолошки) шок било сазнање да оно што они познају као грчки језик нема готово никакве везе са оним што чују као грчки (у Грчкој, или пре од Грка који долазе у Европу).

Устанак и стварање савремене грчке државе били су приоритет, тако да је пет деценија (1830-1880) књижевни језик дремао ушушкан у љуштуру лажног класичног сјаја без обзира што се назирао раскол ${ }^{13}$ по питању употребе народног језика (тзв. ,језичко питање“). Како је, међутим, удаљавање од говорног грчког бивало је све наметљивије, а несувисла архаизација једино сматрана „прогресивном“, тако је све више растао отпор насиљу над језиком, прво код песника ${ }^{14}$, а онда код прозних и драмских писаца ${ }^{15}$ : Како да обични људи говоре необичним језиком и да свакодневни живот описују језиком чијих речи нема у том животу? - на то питање је Јанис Психарис (Жан Психари), филолог и књижевник одговорио својим научним и књижевним делом. Он је 1888. године објавио прозно дело, путопис Моје йуйовање, које је представљало прекретницу. Било је написано чистом димотиком, за оно време екстремном, представљајући радикални заокрет у односу на катаревусу учених и образованих, тако да је правац назван иссихаризмом.

Све је ипак остало на нивоу академске размене мишљења између оних који су се бавили језиком (песници) и оних који су се бави-

13 Раскол је настао прво у поезији, јер народни израз није схватан ништа више него као песничка слобода и стилска особитост. Самим тим димотика, живи језик грчког народа, који се као такав и даље мења, постала је прихватљива у поезији (песник Соломос и Јонска школа), али не и у прози и свему што је било везано за званични (јавни) дискурс. Ту заједничком језику или димотици није било места.

14 Песници су се према „употреби“ димотике и катаревусе делили на Јонску школу, са Соломосом на челу (бел. 13) и на Стару атинску школу, мада је било оних који су их „комбиновали“. Катаревуса је била до те мере „пречишћена“ да је постала извештачена и практично „окамењена“.

15 Генерација осамдесетих (1880-1890). 
ли науком о језику (филолози), све док димотика није „дирнула“ у прозу или класике (нарочито превод Библије и Есхила ${ }^{16}$ на димотику). Нимало академска расправа једних и других присталица прелила се на читаву грчку заједницу и прерасла у друштвени сукоб широких размера.

Продор димотике у „забрањену земљу“ катаревусе изазвао је бурну реакцију, у неколико наврата и насилне акције. Године 1901. у

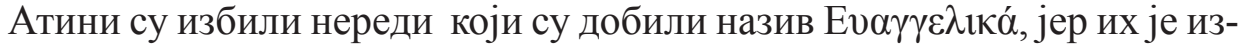
азвао димотички превод Новог завета, и поново 1903. када је изведен Есхил на полу-димотици. Захтеви да се образовни процес изводи на народном језику довео је до уставне одлуке 1911, којом се катаревуса проглашава службеним језиком, а свако кршење кажњава по закону. Упркос томе већ 1913. уводе се текстови на димотици у основне школе $^{17}$. С презиром је одбачена могућност увођења народног језика у средње и високо образовање, али најмање са културних разлога - политика је била та која је одлучивала, позивајући се на то да су национално јединство, идентитет, интегритет у опасности, добро познате флоскуле са опасним дејством.

Најзад, после готово два века више или мање жестоких сукоба, уследио је крај катаревусе и самим тим диглосије, победила је димотика ${ }^{18}$, с тим што је неминовно црпла из рога изобиља старог, Сократовог, језика, директно или посредством латинског (и трећих језика), у процесу који су мање-више прошли сви остали европски језици. Оно по чему се грчки разликује од других језика јесте позиција класичног грчког какву нема ниједан стари језик неког савременог (латински није стари језик неког одређеног (романског) језика). Многе се грчке речи пишу (исто) као класичне, али иако не звуче исто и не мењају се исто, и најзад не значе исто, оне јесу исти, грчки језик. Отуда ,језичко питање“ више него било каква друга расправа говори у прилог једном и јединственом грчком језику, који и даље има две намене: као живи језик грчког народа, флексибилан и изражајан, и, као класични, којим се не говори, али без којег не би било интернационалног језика науке и опште културе.

16 Есхилове драме као канон трагедиографа нису смеле бити, најблаже речено, наружене „преводом“ на димотику.

17 Настава је потпуно прешла на димотику између 1917. и 1920. године.

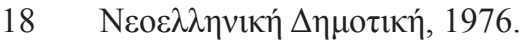




\section{Срби}

Славенски или славено-српски, језик који ће током 19. века бити предмет спорења његових присталица и опонената који су се залагали за Вуков језик, није имао шири значај, у европским оквирима, као што је имао класични грчки ${ }^{19}$, односно, значио је нешто само Србима. Треба истаћи још једну разлику: Срби су се у 18 . веку суочили са питањем језика под Хабзбурговцима, али не у смислу „интерне“ диглосије него како избећи асимилацију у туђој земљи ${ }^{20}$, после већих и мањих сеоба. Главна се борба водила за право на више образовање, односно за оснивање гимназија као виших школа, као и за оснивање штампарије. С обзиром да је црква била надлежна за образовање, митрополити су имали одлучујућу реч и, што је још важније, умели су да се изборе за права и аутономију, заснованих на царским привилегијама ${ }^{21}$, што је трајало читав век. Док су околности биле повољне, власти су настојале да ограниче права Срба, а кад год би Хабзбуршка монархија запала у кризу 22 , нарочито ратну, Срби су у својству граничара били у прилици да се изборе за своја права. Они су то и радили, корак по корак, али упорно, тако да се 1727. у Карловцима отворила Суворовљева руско-словенска школа, пошто се митрополит Мојсије Петровић ${ }^{23}$ изборио за дозволу да се, поред основних, могу оснива-

19 Питање је да ли је већини Грка, поготово оним необразованим, класични језик могао значити нешто посебно, поготово у европским оквирима.

20 Србима нису биле нимало склоне ни отоманске ни аустријске власти, трудећи се да их асимилују (прве мање, друге више) и у верском и у националном смислу.

21 Привилегије су давале Србима персонална права, као припадницима народне и верске заједнице: слободу вере, слободу избора војводе, ослобођење од дажбина и обавеза. Надлежност верског поглавара обухватала је и школску аутономију.

22 Хабзбуршке власти су у повољним по њих околностима настојале да ограниче права Срба, чега се нису либиле ни угарске власти, а ни црквене (српске).

23 Он је молио 1718. и 1721.године руског цара Петра Великог да му пошаље учитеље и књиге за руско-словенску школу, у којој би се учио и нешто мало латински језик. Тако су 1726.године дошла из Русије прва два учитеља, браћа Максим и Петар Суворов, а стигло је и 400 буквара Теофана Прокоповича, 70 граматика Мелетија Смотрицког и 10 Поликарпових тројезичних речника (словенско-латинско-грчки речник, издат 1704. у Москви). 
ти српске средње школе. Будући да је латински био званични језик, особито у Угарској, потребе за зналцима латинског биле су велике, а мало је Срба познавало овај језик ${ }^{24}$. Митрополит и други угледни људи били су стога присиљени да се обраћају странцима ("да не призивамо иноплеменике на помоћ на сваком месту"25). Странци, опет, не само да су скупо наплаћивали своје услуге него су били и непријатељски расположени према оправданим српским захтевима. Суворов, међутим, иако је био обавезан да предаје и латински језик, ипак је отезао с наставом латинског у страху од унијаћења, али је напослетку почео да га предаје 1729. године, без уџбеника, бар у почетку, уз помоћ својеручно израђене абецеде.

Питање штампарија је најзад решено у време митрополита Павла Ненадовића, великог прегаоца, који је готово двадесет година радио у корист српског школства ${ }^{26}$. Србуље су, наиме, у почетку биле једини уџбеници, али нису прештампаване, јер власти у Монархији нису Србима дозволиле њихову штампарију. Они су проблем решили тако што су увозили руске књиге, на које се плаћала висока заштитна царина, због чега је процветало кријумчарење. То је напослетку довело до забране увоза руских књига 1727. године. Да би се онемогућио руски утицај, коначно је одобрено отварање српске штампарије (1750), али је заправо отворена тек 1769 , и то у Бечу, а не у Карловцима како је митрополит тражио.

У последњој четвртини 18. века, 1777. године, царица Марија Терезија је спровела опсежну и радикалну реформу образовања ${ }^{27}$ у чему је одвајање цркве од државе представљало епохалну промену, што никако није могло заобићи Србе, без обзира што је за њих црквена власт била и даље одлучујући фактор по питањима црквене и школ-

24 Најбоље се могао научити у католичким школама.

25 Р. Грујић наводи према Г. Витковић, Споменици из будимског и пештанског архива, Гласник Срйскоі ученої ярушӣва, II одељ, књ. III (Р. Грујић, Срйске школе (og 1718-1739.ì), Задужбина И. М. Коларца 130, Београд 1908, стр. 5).

26 Митрополит Павле Ненадовић је захтевао да свештеници буду школовани у правом смислу те речи, да, на пример, познају латински језик како би се изборили са судством, законима, речју са државном администрацијом. Осим тога, није правио разлику између мушке и женске деце, између имућних и сиромашних, свештенства и осталих Срба.

27 Ratio educationis publicae totiusque rei literariae per Regnum Hungariae et provincias eidem adnexas. 1777. 1806. 
ске аутономије. Срби су коначно основали Карловачку (1791) и Новосадску гимназију (1810), по угледу на најбоље школе у Монархији, чиме су крунисана њихова дугогодишња настојања да се изједначе у погледу виших ${ }^{28}$ школа са осталим народима у Хабзбуршкој монархији. Митрополит Стеван Стратимировић одиграо је ако не кључну а оно веома важну улогу. Питање језика у вишим школама, као што су биле гимназије, није се ни постављало, јер је латински био школски језик ${ }^{29}$. Није се постављало ни питање административног језика, јер је латински у свему доминирао, имајући у виду мешавину народа и језика у Монархији. У то време још увек није било разлога за проблематизовање језика у смислу дефинисања идентитета сваке друштвене заједнице. Питање аутономије, бар када је реч о српској заједници, тицало се, као што је речено, вероисповести и других права, чије ускраћивање или непоштовање није угрожавало српски језик, који је био, могло би се рећи, готово приватна ствар појединца. Зато се у то време митрополит Стратимировић и залагао за стварање књижевног језика, у којем би било елемената и црквено-рускословенског и народног језика ${ }^{30}$, па је саставио по свим правилима класичних књижевних модела, који подразумевају моралну поуку и висок стил, поучну песму Љубосава и Раgован, „по начину простонародних српских песама“"31. Песма јесте по начину (десетерац), како каже, простонародна, али не и по језику, а нимало по писму.

Међутим, могућност вишег образовања у српским гимназијама из корена је променила ситуацију, јер су Срби добили шансу да се образују

28 Архигимназије су биле највише што су могли имати мањински народи Срби су добили право на гимназије као највише школе.

29 Карловци су административно и фактички припадали Граници, или Крајини, што је значило да су били под директном управом Беча, док је Нови Сад административно припадао Провинцијалу, односно Пешти. Међутим, Новосадска гимназија је била под ингеренцијом српског митрополита, који је одредио да се исти модел примени на обе гимназије, чиме је избегао проблем са немачким или мађарским утицајем. .

30 Стратимировић је скупљао народне песме које „слепци и слепице певају на саборима и други часни људи при трпези и весељу“, препоручивао их као одраз „народног духа“, и сам их састављао у неримованом десетерцу (као поменуту песму).

31 Књижица има 20 страна, у првој половини песме мајка поучава ћерку Љубосаву шта су брачне и мајчинске дужности, а у другој отац саветује сина Радована како да се понаша према жени, јер је дужност мајке да васпитава само ћерке, а очева да васпитава синове. 
у сопственим школама, са благодејанијем и другим повољностима ${ }^{32}$, поготово што су људи били имућнији и спремнији да образују потомство све до универзитетског нивоа. Тако су центри образовања и самим тим културе постали Карловци и Нови Сад, па је ту и била највећа концентрација образованих људи који су чинили „Карловачки круг“ и „Новосадски круг“. Образовани људи нису више морали припадати стаду коме је пастир неприкосновени ауторитет, у свему па и у питањима језика, и то се код Срба у Војводини појавило као „књижевно питање““, у доброј мери сведено на питање ортографије, али је било много више од ортографије. Преписка између Вука и Мушицког прати феномен како је криза моћи у једној малој друштвеној заједници довела до епохалне промене, битне наравно за ту заједницу, у књижевности и помоћу књижевности.

На Србију се питање језика прелило касније, на исти начин као у Војводини, што је било неминовно с обзиром да су у Србију долазили образовани Срби из Војводине, што је једна од великих заслуга Милоша Обреновића. Зна се како се завршила Вукова борба за српски језик тако што су и присталице и противници, и онда као и данас, и говорили и писали по Вуковим правилима. Изборивши се за језик којим говоре и који разумеју када њиме пишу ${ }^{33}$, Срби су стекли писмо које се оправдано сматра потпуно фонетским, дакле најсавршеније писмо.

\section{Закључак}

Последња четвртина 18. и прва половина 19. века биле су пресудне и за грчко и за српско језичко питање, јер ће се, у једном тренутку, свака заједница за себе, са сопственим посебностима, успети да се ослободи (наметнуте) диглосије сопственим снагама ${ }^{34}$, што ће и код једних и код других довести до процвата у књижевности и истовремено у култури.

32 Држава није ништа финансирала, све је то радила заједница, у овом случају српска, којој школа треба. То није било строго подељено, јер су Срби и раније слали децу у католичке и друге школе.

33 Лукијан Мушицки је писао оде, једне славенским, друге српским језиком, онако како је сматрао да треба, али зато писма лепим, народним, језиком образованог човека.

34 Грцима је био потребан „дугачак“ 19 век, на чијем су почетку Рига од Фере и Соломос, а на крају Психарис и Кариотакис. Србима је требало мање времена, али је и њихов терет био мањи. 
И код Грка и код Срба „интерна““ диглосија и борба за народни језик су биле сличне, сличан је био и отпор црквених власти, јер се борба водила против наметања језика којим се успоставља граница између образованих и необразованих, односно, против књижевног језика који није био стандардан у смислу заједничког језика друштвене заједнице која њиме природно говори. Таква борба се могла повести тек када су се стекли услови, зато је геополитички оквир важан, али не и пресудан. Наиме, и један и други народ се борио за ослобођење (од турске власти), као што је и један и други народ био располућен на „европски“ и „неевропски“ део и сходно томе са различитим односом према европској култури. Можда је сувишно истицати да су грчки језик и хеленска култура одиграли више него значајну улогу у културној историји српског народа, али никако није сувишно истаћи да је рецепција духовног наслеђа античке Грчке код нас била непосредна, успостављањем културних веза у најширем смислу те речи, српског и осталих балканских народа с Грцима.

\section{Литература}

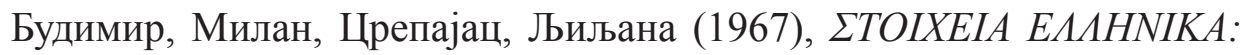

Основи ірчке їлойолоїије. Београд: Завод за издавање уџбеника Социјалистичке републике Србије.

Vučo, Julijana (2009), Kako se učio jezik. Pogled u istoriju glotodidaktike: od prapočetaka do drugog svetskog rata. Ministarstvo za nauku i zaštitu životne sredine. Filološki fakultet: Beograd.

Гавриловић, Никола (1984), Карловачка боїословија (1794-1920). Сремски Карловци: Српска православна богословија Св. Арсенија, књ.1. Грујић, Радослав М. (1908), Срйске школе (og 1718-1739 ї.). Београд: Издање Задужбине И. М. Коларца 130.

Грујић, Радослав М. (1910): Прилози за исӣорију срисских школа у I йоловини XVIII века. Београд: Српска краљевска академија. Споменик, књ. 49

Јовановић М. (2003), Гgе извире бескрај све је целина. Из хеленске поезије. Résumé : La ou l'infini prend sa source tout est unité (Choix de poésie hellénique), 277-296. Index, 297-317. Београд. Источ- 
ник. Библиотека Искони. 2003. Стр. 320.

URLhttp://www.neohelenistika.com/pdf/jovanovic_gde_izvire_beskraj.... pdf

Јовановић М. (2010), Из Хермесове йалестире. Прилої истиорији класичне филолоїије коg Срба. - Београд: Филолошки факултет. Доступно на адреси: www.neohelenistika.com

Караџић, В. С. (1966-1995), Сабрана gела Вука Караџића. Књ. ХХXXVII. Прейиска. I - VIII. Београд: Просвета.

Кириловић, Димитрије (1956), Карловачке школе у gоба мийройолийа Павла Ненаgовића. Београд: Српска краљевска академија Споменик CIV. Одељење друштвених наука. Нова серија 6, 45117.

Mackridge, P. (1985), The modern Greek language : a descriptive analysis of standard modern Greek. Oxford : Oxford University Press, 1985, XXIII, 387. ISBN 0198157703

Psichari J. (1886), Essais de grammaire historique néo-grecque I, Paris : Ernest Leroux. [En ligne], URL : http://anemi.lib.uoc.gr/ metadata/1/f/7/metadata-172-0000039.tk1

Psichari, J. (1889), Essais de grammaire historique néo-grecque II, Paris : Ernest Leroux. [En ligne], URL : http://anemi.lib.uoc.gr/ metadata/1/f/7/metadata-172-0000039.tkl

Psichari J. (1892), Etudes de philologie néo-grecque : recherches sur le développement historique du grec. Paris : E. Bouillon. [En ligne], URL :

http://www.archive.org/stream/tudesdephilolog00psicgoog\#page/n101/ mode/2up

Psichari J. (1897), Autour de la Grèce. Paris : C. Levy.

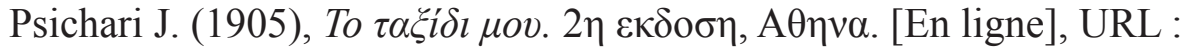

(http://www.sarantakos.com/kibwtos/mazi/psuxarhs_taksidi.htm).

Стајић, Васа (1949), Срйска ирравославна велика іимназија у Новом Cagy. Нови Сад: Матица српска.

Holton, D., Mackridge, P., Philippaki-Warburton, I. (2004), Greek : a comprehensive grammar of the modern language. London; New York: Routledge, 519. ISBN 0415100011 
Milena Jovanović

\section{Summary}

\section{"LANGUAGE QUESTION" IN GREECE AND SERBIA}

At first glance, culture and crisis have nothing in common. Moreover, it might look like one phenomenon excludes the other, in a sense of inter arma, tacent musae. History shows that there is a certain reciprocity between crisis and culture, but not in a way that they have to be conditioned by one another. When culture falters in difficult times, crisis can act as a kind of booster, since both represent human activity, which implies a conscious activity. Ancient Greece is practically an inexhaustible source of examples for conducting research on the (mutual) relationship between culture and crisis, especially when it comes to language, and it was not much different in centuries to follow. The Greek language and literature, and its over thirty centuries long tradition, make this kind of research possible. Finally, both Greeks and Serbs, regardless of all the differences, followed a similar path, mostly guided by the geopolitical situation of the new era. Psiharis

Key words: diglossia, Demotic Greek, "language issue", Greeks, Serbs, 